JURNAL MAKSIPRENEUR, Vol. VI, No. 2, Juni 2017, hal. 18 - 26

\title{
PENENTUAN PEMILIHAN OPERATOR SELULER DENGAN METODE ANALISIS EFEKTIFITAS
}

\author{
Edy Suhartono \\ Fakultas Ekonomi Universitas Bojonegoro \\ Bambang Sri Wibowo \\ Sekolah Tinggi Ilmu Ekonomi Mahardhika Surabaya \\ Korespondensi penulis: edysuhartono999@gmail.com
}

\begin{abstract}
This study aims to examine the influence of advertising in print media, electronic media, and social media to consumer decisions in choosing Telkomsel cellular operators, the magnitude influence of each independent variable and the most dominant variable influence the consumer decisions. This study explains the relationship between research variables through hypothesis testing. The data collection method in this research is survey with questionnaire tools. Population in this research is all of the consumer of Telkomsel cellular operator. The quantity of sample used in this research is 40 respondents. Hypothesis testing uses multiple regression analysis. Based on the results of data analysis in this research indicate that the variables of print media, electronic media, and social media influence to consumer decisions. The magnitude of influence of print media is $7 \%$, electronic media $27.7 \%$, and social media $41.1 \%$. The most dominant influence of the variable is the print media variable.
\end{abstract}

Keywords: advertising media, consumer decision, cellular operator.

\section{PENDAHULUAN}

Pada umumnya, perusahaan mengalami kesulitan dalam memonitor, memahami, dan menganalisis perilaku konsumen secara tepat dan benar, mengingat banyaknya faktor yang mempengaruhi perilaku konsumen dan adanya perbedaan perilaku untuk masing-masing individu. Dengan demikian, perusahaan dituntut untuk dapat memantau perubahan-perubahan perilaku konsumennya, termasuk perilaku konsumen untuk mendapatkan atau memilih suatu produk. Ada banyak faktor yang mempengaruhi konsumen membeli suatu produk. Faktor-faktor yang mempengaruhi konsumen mempunyai peran yang berbeda untuk produk yang berbeda pula. Pemasar dituntut untuk jeli dalam mengamati perilaku konsumen tersebut. Melalui pengamatan terhadap perilaku konsumen akan didapatkan strategi pemasaraan yang benar dan tepat sasaran. Banyak upaya yang dilakukan pemasar dalam memasarkan produknya. Salah satunya adalah kegiatan promosi. Promosi adalah upaya mengkomunikasikan informasi atau persuasi kepada pembeli potensial atau orang lain dalam saluran pemasaran untuk mempengaruhi sikap dan perilaku. Tujuan dari perusahaan melakukan promosi adalah untuk mengenalkan barang dan jasa yang diproduksinya agar konsumen tertarik untuk membeli, target penjualan tercapai, dan perusahaan mendapatkan laba. Media periklanan yang digunakan dalam promosi pun sangat variatif di antaranya adalah media cetak, media elektronik, dan media sosial. 
Banyak perusahaan memanfaatkan media-media periklanan tersebut. Salah satunya adalah perusahaan operator seluler. Dewasa ini, telepon seluler atau yang lebih dikenal masyarakat dengan sebutan handphone atau ponsel merupakan satu barang yang sangat penting untuk menunjang komunikasi, sebagai media aktualisasi diri, dan pencarian informasi. Handphone tidak lagi menjadi barang yang mewah, hal ini dikarenakan pasar handphone di Indonesia yang semakin ramai ditandai dengan makin murahnya harga ponsel. Meningkatnya fasilitas dan layanan pada pelanggan merupakan respon perusahaan terhadap persaingan. Di sisi lain, terjadi peningkatan kebutuhan masyarakat di berbagai kalangan akan informasi secara umum melalui ponsel. Sistem pengoperasian handphone dapat dilakukan melalui sebuah kartu seluler atau SimCard. Kartu seluler berisikan fasilitas-fasilitas layanan dan fitur-fitur menarik yang ditawarkan perusahaan kartu seluler. Fasilitas-fasilitas layanan dapat berupa kekuatan sinyal untuk menjangkau seluruh daerah, pesan teks dan gambar cepat dikirim dan diterima, tempat menyimpan nomor telepon, dan lain-lain. Fitur-fitur kartu seluler berupa kemudahan memperoleh informasi berita, jadwal penerbangan, horoscope, dan lain-lain. Berarti secara tidak langsung pulsa operator seluler telah menjadi kebutuhan primer bagi masyarakat pengguna handphone. Banyak operator seluler yang beroperasi di Indonesia. Salah satu perusahaan layanan yang cukup besar adalah Telkomsel. PT. Telkomsel adalah perusahaan operator telepon seluler terkemuka dengan pangsa pasar yang besar. GSMA Intelligence hingga kuartal ketiga tahun 2015 menobatkan Telkomsel sebagai operator seluler paling dominan di Indonesia. Telkomsel menguasai pangsa pasar sebesar 45\% (WE Online Jakarta, 2015).

\section{KAJIAN PUSTAKA \\ a. Periklanan}

Menurut Kotler (2003), iklan adalah segala bentuk aktifitas yang dilakukan untuk menghadirkan dan mempromosikan ide, barang, atau jasa secara non-personal dengan biaya tertentu. Kotler juga mengatakan untuk membuat pasar menerima pesan dari iklan. Para pemasar memerlukan sebuah wahana yang bisa mendrive pola pikir dari calon-calon pelanggan tersebut. Ada pun definisi menurut Dharmmesta (2002: 245) menyatakan "periklanan adalah komunikasi non-individu dengan sejumlah biaya melalui berbagai media yang dilakukan oleh perusahaan, lembaga, non-lembaga, serta individu-individu." Periklanan bersifat menjangkau masyarakat luas (massal), tidak pribadi, tetapi secara langsung dengan audien (impersonal) dan dapat menyampaikan gagasan secara meyakinkan dan menimbulkan efek yang dramatif (ekspresif). Tujuan periklanan terutama adalah untuk menjual atau meningkatkan penjualan barang, jasa, atau ide. Kegiatan periklanan sering mengakibatkan terjadinya penjualan dengan segera, meskipun banyak juga penjualan yang baru terjadi pada waktu mendatang (Dharmmesta, 2000: 252). Ada pun beberapa tujuan lain periklanan adalah: (1) mendukung program personal selling dan kegiatan promosi lainnya, (2) mencapai orang-orang yang tidak dapat diraih oleh tenaga penjualan atau salesman dalam jangka waktu tertentu, (3) mengadakan hubungan dengan para penyalur, misalnya dengan mencantumkan nama dan alamatnya, (4) memasuki daerah pemasaran baru atau menarik pelanggan baru, dan (5) memperkenalkan produk baru dan menambah penjualan industri.

Dharmmesta (2002: 246) menyatakan bahwa "beberapa fungsi periklanan antara lain memberikan informasi, membujuk atau mempengaruhi, menciptakan kesan, 
memuaskan keinginan, dan sebagai alat komunikasi." Ada pun fungsi-fungsi periklanan adalah:

(1) Memberi informasi yaitu periklanan dapat menambah nilai pada suatu barang dengan memberikan informasi kepada konsumen. Iklan dapat memberikan informasi lebih banyak daripada lainnya, baik tentang produknya, harganya, ataupun informasi lain yang mempunyai kegunaan bagi konsumen. Nilai yang diciptakan oleh periklanan tersebut dinamakan faedah informasi. Tanpa adanya informasi seperti itu orang segan atau tidak akan mengetahui banyak tentang suatu produk;

(2) Membujuk atau mempengaruhi yaitu bahwa periklanan tidak hanya bersifat memberikan informasi saja, tetapi juga bersifat membujuk terutama kepada pembeli-pembeli potensial dengan menyatakan bahwa suatu produk adalah lebih baik daripada produk lain. Dalam hal ini, iklan yang sifatnya membujuk tersebut lebih baik dipasang di media-media periklanan yang mudah untuk diakses.

(3) Menciptakan kesan dengan sebuah iklan agar orang mempunyai kesan tertentu tentang apa yang diiklankan. Dalam hal ini, pemasangan iklan selalu berusaha untuk menciptakan iklan yang sebaik-baiknya. Periklanan juga dapat menciptakan kesan pada masyarakat untuk melakukan pembelian secara rasional dan ekonomis.

(4) Memuaskan keinginan sebelum memilih dan membeli produk, karena kadangkadang orang ingin diberitahu lebih dulu mengenai informasi lengkap tentang suatu produk. Periklanan menjadi alat komunikasi yang sangat efisien bagi para pemasar.

(5) Alat komunikasi yaitu periklanan akan membuka komunikasi dua arah antara penjual dan pembeli, sehingga kenginan mereka dapat terpenuhi dengan cara yang efisien dan efektif. Dalam hal ini, komunikasi dapat menunjukkan caracara untuk mengadakan pertukaran yang saling memuaskan.

\section{b. Media Iklan}

Banyak media iklan di antaranya adalah media cetak, media elektronik, dan media sosial. Media cetak adalah suatu media yang bersifat statis dan mengutamakan peranperan visual. Media ini terdiri atas lembaran dengan sejumlah kata, gambar, atau foto dalam tata warna dan halaman putih. Seperti televisi dan radio dalam jajaran medium penyiaran, fungsi media cetak adalah member informasi dan hiburan. Media ini berbeda dengan media elektronik dalam hal kemampuannya untuk menyampaikan informasi. Media cetak adalah suatu dokumen atas segala hal yang dikatakan orang lain dan rekaman peristiwa yang ditangkap oleh sang jurnalis dan diubah dalam bentuk katakata, gambar, foto dan sebagainya.

Media elektronik adalah media yang menggunakan peralatan elektronik atau energi elektromekanis bagi pengguna akhir untuk mengakses kontennya. Sumber media elektronik yang familiar bagi pengguna secara umum, antara lain adalah rekaman video, rekaman audio, presentasi multimedia, dan konten daring. Contoh dari media elektronik di antaranya adalah: (1) Televisi yaitu media iklan atau promosi yang banyak dikenal oleh masyarakat dan efektif untuk melakukan pemasaran. Hal ini dikarenakan televisi sangat mudah diakses oleh segala lapisan masyarakat. Televisi memiliki daya jangkauan yang sangat luas, sehingga kemungkinan suatu iklan dilihat masyarakat sangat tinggi. Televisi bisa menampilkan wujud produk yang dipromosikan, sehingga pelanggan bisa mengetahui terlebih dahulu bentuknya. (2) Radio adalah saluran promosi yang sangat 
umum dikenal oleh masyarakat. Radio memiliki daya jangkauan terbatas biasanya di perkotaan besar. Akan tetapi, seiring dengan berkembangnya teknologi, radio sudah bisa menembus batas wilayah kota dengan menggunakan teknologi internet melalui streaming. Beriklan di radio, pemasar tidak bisa memperlihatkan produknya kepada konsumen, tetapi dengan bantuan tim kreatif, iklan di radio dibuat seakan-akan mendatangkan visual kepada otak pendengar. Radio memiliki pendengar yang sudah terbagi-bagi sehingga memudahkan pemasar untuk melakukan kegiatan promosi sesuai segmen pasar.

Media sosial menurut Kaplan dan Haenlein (2008) adalah sebuah aplikasi yang berbasis HTML dan internet dengan konsep dan dasar teknologi web 2.0 yang memungkinkan para penggunanya bebas untuk menciptakan dan membagi content yang dibuat secara pribadi. Media sosial juga merupakan salah satu bagian dari pemasaran dengan konsep $M$-commerce (mobile commerce), yaitu pemasar mempromosikan barang atau jasanya melalui peralatan elektronik nirkabel (Solomon, 2011). Menurut Kaplan dan Haenlein (2008), ada beberapa klasifikasi dan contoh media sosial di antaranya:

(1) Proyek kolaborasi (collaborative project), suatu media sosial yang dapat membuat konten dan dalam pembuatannya dapat diakses secara global. Ada dua sub kategori yang termasuk di dalam collaborative project dalam media sosial, yaitu: (a) wiki adalah situs yang memungkinkan penggunanya untuk menambahkan, menghapus, dan mengubah konten berbasis teks. Contoh: Wikipedia, Wiki Ubuntu-ID. (b) aplikasi bookmark sosial yang memungkinkan adanya pengumpulan berbasis kelompok dan rating dari link internet atau konten media, contoh: social bookmark: Digg, Del.ici.us, StumbleUpon, Reddit, Technorati, Lintas berita, infogue. Writing: cerpenista, kemudian.com. Reviews: Amazon, GoodReads, Yelp.

(2) Blog dan microblog adalah aplikasi yang dapat membantu penggunanya untuk tetap posting mengenai pernyataan apapun sampai seseorang mengerti. Blog sendiri ialah sebuah website yang menyampaikan mengenai penulis atau kelompok penulis baik itu sebuah opini, pengalaman, atau kegiatan sehari-hari. Contoh, Blog: blogspot (blogger), wordpress, multiply, live journal, blogsome. Microblog: twitter, tumbler, posterous, koprol, plurk. Forum: kaskus, Warez-bb, indowebster.web.id, forum detik. Q/A (Question/Answer): Yahoo! Answer, Tanyalinux, formspring.me.

(3) Content communities atau konten masyarakat adalah sebuah aplikasi yang bertujuan untuk saling berbagi dengan seseorang, baik itu secara jarak jauh maupun dekat berbagi seperti video, ebook, gambar. Contoh, Image dan photo sharing: Flickr, photobucket, DevianArt. Video sharing: Youtube, vimeo, Mediafire.Audio dan Music sharing: Imeem, Last.fm, Sharemusic, multiply. File sharing dan Hosting: 4shared, rapidshare, Indowebster.com. Design: Threadles, KDRI (Kementrian Disain Republik Indonesia).

(4) Situs jejaring sosial (social networking sites) merupakan situs yang dapat membantu seseorang untuk membuat sebuah profil dan kemudian dapat menghubungkan dengan pengguna lainnya. Situs jejaring sosial adalah aplikasi yang memungkinkan penggunanya untuk terhubung menggunakan profil pribadi atau akun pribadinya, Contoh: facebook, instagram, twitter.

(5) Virtual game worlds, dunia virtual untuk mereplikasikan lingkungan 3D, yaitu user bisa muncul dalam bentuk avatar yang diinginkan serta berinteraksi dengan orang lain selayaknya di dunia nyata. Contoh: clash of clan, clash royal, three kingdoms. 
(6) Virtual social worlds merupakan aplikasi yang mensimulasikan kehidupan nyata melalui internet. Virtual social worlds adalah situs yang memungkinkan pengguna untuk berinteraksi dalam platform tiga dimensi dengan menggunakan avatar yang mirip dengan kehidupan nyata. Contoh, Map: wikimapia, GoogleEarth. Ecommerce: ebay.

\section{c. Keputusan Pemilihan Pembelian Produk dan Jasa}

Suatu proses keputusan memilih bukan sekedar mengetahui berbagai faktor yang akan mempengaruhi keputusan dalam memilih, tetapi berdasarkan peranan dalam memilih dan keputusan untuk memilih. Ada pun pihak-pihak yang terlibat atau berperan dalam sebuah proses keputusan memilih (Mangkunegara, 2002) adalah sebagai berikut: (1) Pengambilan inisiatif adalah orang yang pertama-tama menyarankan atau memikirkan ide memilih barang atau jasa tertentu; (2) Memilih pengaruh adalah orang yang pandangan dan nasehatnya berperan cukup besar dalam memilih keputusan akhir; (3) Pengambil keputusan adalah orang yang pada akhirnya menentukan sebagian atau keseluruhan keputusan; (4) Pemakai adalah orang yang memakai dan menggunakan barang atau jasa tersebut; (5) Pembeli adalah orang yang melakukan pembelian sebenarnya.

Secara definitif dikemukakan oleh Terry yang dikutip oleh Simamora (2002) menyatakan bahwa pengambilan keputusan adalah sebagai pilihan yang didasarkan atas kriteria tertentu mengenai alternatif kelakuan tertentu daripada dua buah alternatif yang lebih. Dari definisi tersebut diketahui bahwa keputusan konsumen itu akan menentukan proses pengambilan keputusan dalam memilih. Proses tersebut merupakan sebuah pendekatan penyelesaian masalah yang menurut Kotler dan Keller (2008) memiliki lima tahap proses memilih yaitu: (1) Pengenalan masalah yaitu menyadari suatu perbedaan antara keadaan sebenarnya dengan keadaan yang diinginkannya. Kebutuhan itu dapat digerakkan oleh rangsangan dari dalam pembeli maupun dari luar pembeli. Rangsangan dari dalam biasanya berasal dari adanya perubahan daya memilih, pergeseran struktur ketenagakerjaan, pergeseran pola pendapatan, dan pergeseran pola konsumen. Hal ini dapat menjadi sumber rangsangan dari dalam karena dapat membuat seseorang merasa lebih sejahtera, memiliki peranan yang lebih penting atau sebaliknya, sehingga akan mengubah kebutuhan atau pun keinginannya. Ada pun rangsangan dari luar penglihatan sendiri seperti teman, tetangga, atau pun iklan tentang adanya sesuatu yang baru dan lebih baik dari yang sudah ada; (2) Pencarian informasi muncul apabila konsumen mulai tergugah minatnya terhadap sesuatu untuk memenuhi kebutuhan maupun keinginannya.

Dalam tahap mencari informasi dapat dibagi menjadi dua, yaitu: (a) konsumen dalam tahap perhatian meningkat ditandai dengan usahanya mencari informasi dalam ukuran sedang-sedang saja, dan (b) konsumen dalam tahap berusaha aktif mencari informasi, yaitu dengan usahanya mencari bahan bacaan, bertanya pada teman-teman untuk menghimpun informasi tentang suatu produk; (3) Penilaian alternatif dalam tahap ini tidak ada suatu proses penilaian sederhana dan tunggal yang dapat dipergunakan oleh semua konsumen. Model yang paling baru tentang proses penilaian alternatif adalah orientasi kognitif, yakni memandang konsumen sebagai pembuat pertimbangan mengenai produk terutama berlandaskan pada pertimbangan yang sadar dan rasional; (4) Keputusan memilih dalam tahap ini, konsumen dapat juga berbentuk suatu maksud memilih produk yang disukai. Namun, ada dua faktor lain yang dapat mencampuri maksud memilih tersebut untuk menjadi keputusan memilih, yaitu sikap orang lain baik yang positif maupun yang negatif dan faktor-faktor situasional yang tidak terduga 
seperti misalnya hilangnya pekerjaan, munculnya keperluan lain yang lebih penting atau keluhan seseorang tentang pelayanan dan kejelekan suatu produk; (5) Perilaku setelah memilih yaitu tahap kelima, setelah memilih produk, konsumen akan mengalami beberapa tingkat kepuasan atau ketidakpuasan. Konsumen juga akan melakukan beberapa tingkah laku setelah memilih produk yang akan menarik bagi pemasar. Atau dengan kata lain kepuasan atau ketidakpuasan konsumen terhadap suatu produk yang sudah dipilih mempengaruhi tingkah laku berikutnya.

Tugas para pemasar belum selesai setelah produk dibeli oleh konsumen, namun akan terus berlangsung hingga periode waktu setelah memilih. Setelah proses tersebut tidak selalu dilaksanakan oleh konsumen dalam memilih. Tidak dilaksanakannya beberapa tahap dari proses tersebut hanya mungkin terdapat pada pemilihan yang bersifat emosional. Konsumen akan lebih mudah dalam pengambilan keputusan memilih ulang atau memilih yang sifatnya terus menerus terhadap produk yang sama (termasuk sama dalam harga dan kualitas). Apabila faktor-faktor tersebut berubah, maka pembelian akan mempertimbangkan kembali keputusan-keputusannya, termasuk masalah merk.

\section{METODE PENELITIAN}

Data yang dikumpulkan penelitian ini adalah data kualitatif, yaitu data yang diperoleh dari hasil wawancara dengan pengguna operator seluler Telkomsel. Data kuantitatif, yaitu data dalam bentuk angka yang dapat dihitung, yang diperoleh dari perhitungan kuisioner terkait dengan masalah yang diteliti. Populasi dalam penelitian ini adalah seluruh pengguna operator seluler Telkomsel. Populasi ini dipilih oleh peneliti karena pengguna operator seluler Telkomsel banyak dan lebih mudah diteliti alasan pengambilan keputusannya dalam memilih operator seluler Telkomsel. Teknik pengambilan sampel yang dilakukan menggunakan teknik nonprobability sampling dengan pertimbangan karena populasi penelitian tidak dapat diketahui dengan pasti. Pengujian hipotesis dalam penelitian ini menggunakan analisis regresi linier berganda (multiple regression analysis). Analisis regresi berganda ini digunakan untuk menguji apakah variabel independen (media cetak, media elektronik, dan media sosial) mempengaruhi variabel dependen (keputusan konsumen memilih operator seluler Telkomsel).

\section{HASIL DAN PEMBAHASAN}

\section{a. Uji Hipotesis}

Setelah dilakukan pendiskripsian jawaban responden, tahap selanjutnya adalah pengujian hubungan antarvariabel. Dalam penelitian ini, analisis yang digunakan untuk menguji hipotesis adalah Multiple Regression. Berdasarkan hasil analisis yang dapat dilihat pada output SPSS dapat diketahui besarnya koefesien determinasi (adjusted $R$ square) sebesar 0,125. Hal ini berarti $12,5 \%$ variabel keputusan konsumen dapat dijelaskan atau dipengaruhi oleh variabel independen, yaitu media cetak, media elektronik, dan media social, sedangkan sisanya dijelaskan oleh faktor-faktor lain di luar model.

Uji-t digunakan untuk mengetahui apakah variabel independen yaitu media cetak, media elektronik, dan media sosial secara parsial atau individual berpengaruh pada variabel keputusan konsumen, dengan asumsi variabel lain konstan. Pengujian statistik ini dilakukan pada tingkat keyakinan $90 \%$ dan tingkat signifikasi yaitu $0,1 \quad(\alpha=10 \%)$. Dari output hasil SPSS dapat dijelaskan sebagai berikut: (1) media cetak mempunyai 
nilai t-hitung $=0,445$ dengan nilai signifikasi $(p$ value $)$ sebesar 0,659 adalah lebih besar dari 0,1 artinya bahwa secara parsial media cetak tidak mempunyai pengaruh dan tidak signifikan terhadap keputusan konsumen; (2) media elektronik mempunyai nilai thitung $=1,104$ dengan nilai signifikasi $(p$ value $)$ sebesar 0,277 adalah lebih besar dari 0,1 artinya bahwa secara parsial media elektronik tidak mempunyai pengaruh terhadap keputusan konsumen; (3) media sosial mempunyai nilai t-hitung $=2.642$ dengan nilai signifikasi ( $p$ value) 0,012 adalah lebih kecil dari 0,1 artinya bahwa secara parsial media sosial mempunyai pengaruh signifikan terhadap keputusan konsumen.

Uji-F digunakan untuk mengetahui pengaruh variabel bebas pada variabel terikat secara bersama-sama. Variabel bebas yaitu media cetak, media elektronik, dan media sosial secara bersama-sama berpengaruh pada variabel terikat yaitu keputusan konsumen. Dari uji ANOVA dapat diketahui hasil uji-F menunjukkan bahwa besarnya F-hitung sebesar 2,862 dan tingkat signifikasi sebesar 0,05 artinya bahwa variabel bebas yaitu media cetak, media elektronik, dan media sosial secara bersama-sama berpengaruh pada variabel terikat keputusan konsumen.

Hipotesis menyatakan adanya dugaan media cetak (X1), media elektronik (X2), dan media sosial (X3) berpengaruh secara bersama-sama terhadap keputusan pemilihan operator seluler Telkomsel. Hipotesis ini bertujuan untuk menguji pengaruh variabel media cetak, media elektronik, dan media sosial terhadap keputusan konsumen dalam memilih produk operator seluler Telkomsel. Uji-F digunakan untuk mengetahui pengaruh variabel bebas pada variabel terikat secara bersama-sama. Variabel bebas yaitu media cetak, media elektronik, dan media sosial secara bersama-sama berpengaruh pada variabel terikat keputusan konsumen dalam memilih operator seluler Telkomsel. Berdasarkan hasil perhitungan yang dapat dilihat pada output SPSS dari uji ANOVA dapat diketahui hasil uji-F menunjukkan bahwa besarnya F-hitung sebesar 2,862 dengan tingkat signifikasi 0,050 yang lebih kecil dari tingkat signifikasi 0,1. Artinya, variabel bebas yaitu media cetak, media elektronik, dan media sosial secara bersama-sama berpengaruh pada variabel terikat keputusan konsumen dalam memilih operator seluler Telkomsel, maka dapat disimpulkan bahwa hipotesis 1 didukung.

Hipptesis yang menyatakan adanya dugaan media cetak (X1), media elektronik (X2), dan media sosial (X3) berpengaruh cukup besar dan signifikan terhadap keputusan pemilihan operator seluler Telkomsel. Hipotesis ini bertujuan untuk menguji besarnya pengaruh media cetak, media elektronik, dan media sosial terhadap keputusan konsumen dalam memilih operator seluler Telkomsel. Berdasarkan hasil perhitungan yang dapat dilihat pada hasil output SPSS menyatakan bahwa: (1) nilai t-hitung media cetak sebesar 0,445 dengan tingkat signifikan t hitung adalah 0,659 yang lebih besar dari 0,1 maka dapat disimpulkan bahwa media cetak tidak berpengaruh dan tidak signifikan terhadap keputusan konsumen. Dari tabel output hasil SPSS, nilai standardized coefficient beta variabel media cetak yaitu 0,070, artinya keputusan konsumen dalam memilih operator seluler Telkomsel dipengaruhi oleh variabel media cetak hanya sebesar 7\%; (2) nilai t-hitung media elektronik sebesar 1,104 dengan tingkat signifikan t-hitung adalah 0,277 yang lebih besar dari 0,1 maka dapat disimpulkan bahwa media elektronik tidak berpengaruh dan tidak signifikan terhadap keputusan konsumen. Nilai standardized coefficient beta variabel media elektronik yaitu 0,168, artinya keputusan konsumen dalam memilih operator seluler Telkomsel dipengaruhi oleh variabel media cetak hanya sebesar 16.8\%; (3) nilai t-hitung media sosial sebesar 2,642 dengan tingkat signifikan t-hitung adalah 0,012 yang lebih besar dari 0,1 maka dapat disimpulkan bahwa media sosial berpengaruh dan signifikan 
terhadap keputusan konsumen. Nilai standardized coefficient beta variabel media sosial yaitu 0,411 , artinya keputusan konsumen dalam memilih operator seluler Telkomsel dipengaruhi oleh variabel media sosial sebesar $41,1 \%$.

Berdasarkan dari penjabaran tiga item hasil perhitungan SPSS, karena dari tiga variabel media cetak, media elektronik, dan media sosial hanya satu variabel saja yaitu media sosial yang berpengaruh dan signifikan terhadap keputusan konsumen dalam memilih operator seluler Telkomsel, maka dapat disimpulkan bahwa hipotesis kedua ditolak. Hipotesis menyatakan adanya dugaan bahwa variabel yang paling dominan berpengaruh terhadap keputusan pemilihan operator seluler Telkomsel adalah media sosial (X3). Berdasarkan hasil analisis regresi linier berganda dengan alat analisis SPSS versi 20 menyatakan bahwa variabel media sosial memiliki pengaruh paling dominan di antara variable-variabel lainnya terhadap keputusan konsumen dalam memilih operator seluler Telkomsel. Besarnya pengaruh variabel media sosial yaitu nilai standardized coefficient beta variabel media sosial sebesar 0,411, artinya keputusan konsumen dalam memilih operator seluler Telkomsel ditentukan variabel media sosial sebesar $41,1 \%$.

\section{KESIMPULAN}

Berdasarkan hasil analisis data, maka dapat diambil kesimpulan sebagai berikut: variabel media cetak, media elektronik, dan media sosial berpengaruh bersama-sama terhadap keputusan konsumen dalam memilih operator seluler Telkomsel. Besarnya pengaruh variabel media cetak, media elektronik, dan media sosial terhadap keputusan konsumen dalam memilih operator seluler Telkomsel: (1) Variabel media cetak tidak berpengaruh signifikan terhadap keputusan konsumen dalam memilih operator seluler Telkomsel. Besarnya nilai standardized coefficient beta variabel media cetak yaitu 0,070, artinya keputusan konsumen dalam memilih operator seluler telkomsel ditentukan oleh variabel media cetak hanya sebesar 7\%; (2) Variabel media elektronik tidak berpengaruh signifikan terhadap keputusan konsumen dalam memilih operator seluler Telkomsel. Besarnya nilai standardized coefficient beta variabel media elektronik yaitu 0,277, artinya keputusan konsumen dalam memilih operator seluler telkomsel ditentukan oleh variabel media elektronik hanya sebesar 27,7\%; (3) Variabel media sosial berpengaruh signifikan terhadap keputusan konsumen dalam memilih operator seluler Telkomsel. Besarnya nilai standardized coefficient beta variabel media sosial yaitu 0,411, artinya keputusan konsumen dalam memilih operator seluler Telkomsel ditentukan oleh variabel media sosial sebesar $41,1 \%$. Variabel yang memiliki pengaruh paling dominan terhadap keputusan konsumen dalam memilih operator seluler Telkomsel adalah variabel media sosial.

\section{DAFTAR REFERENSI}

Bilson, S. (2002). Panduan Riset Perilaku Konsumen. Jakarta: PT. Gramedia Pustaka Utama.

Dharmmesta, B.S. (2000). Manajemen Pemasaran Modern. Jakarta: PT. Raja Grafindo Persada.

(2002). Manajemen Pemasaran. Edisi Kedua. Cetakan Kedelapan. Jakarta: Penerbit Liberty. 
Kaplan A. \& Haenlein M. (2008). User of the world, Unite! the Challenges and Opportunities of Social Media. Elsevier.

Kotler, P. (2003). Manajemen Pemasaran. Edisi Kesebelas, Jakarta: Indeks Kelompok Gramedia.

Kotler, P. \& Keller, K.L. (2008). Manajemen Pemasaran. Jilid 1, Edisi 12, PT. Indeks.

Prabu, A.A. \& Anwar, M. (2002). Perilaku Konsumen. Bandung: Refika.

Solomon, M.R. (2011). Consumer Behavior: Buying Having, and Being. Ninth Edition. NewJersey: Pearson Prentice-Hall, Inc.

Weonline. (2015). Ini Urutan Dominasi Operator Seluler Tanah Air. http://m.wartaekonomi.co.id/berita74677/ini-urutan-dominasi-operator-selulertanah-air.html. 